Full length article

\title{
EVALUATING THE EFFECT OF INDUSTRIAL EFFLUENTS ON CHEMICAL COMPOSITION OF SOIL IN VILLAGE DINGI, DISTRICT HARIPUR
}

\author{
K. Asgharl, *, A. Hussain', Z. Malik', A. Asgharl and A. Bibil \\ 1. Department of Environmental Sciences, University of Haripur, Pakistan \\ 2. Forestry and Wildlife Management, University of Haripur, Haripur, Pakistan
}

\begin{abstract}
The present report is an outcome of research work conducted in Dingi village, District Haripur in 2012. The research aimed to assess and analyze the effects of industrial effluents on the soil fertility of the village, investigate contributing factors responsible for soil pollution and underlying causes creating the problems. Data analysis revealed that area had problems pertaining to water and soil quality. The key factors affecting soil fertility were the careless discharge of the untreated industrial effluents from Hattar Industrial Estate (HIE) into the natural stream passing through village. The results were compared with the soil standards set by the World Wide Fund for Nature (WWF) and European Committee Commission (ECC) and all of these were exceeding the permissible limits and affecting the soil fertility. The soils were found not fit for agriculture. The investigation highlighted the need to take some effective steps to manage the monitoring program set for checking of industries by the government according to set rules and regulation.
\end{abstract}

Key Words: Industrial Effluents, Soil Fertility, Heavy Metals, Soil pH, Electrical Conductivity, Polluted Water.

*Corresponding author: (Email: abassi.teej@yahoo.com)

\section{INTRODUCTION}

Soil is composed of weathered parent rocks and fossils of many living and non living organisms. It is the upper most layer of earth crust [1]. The physical, chemical, and biological parameters like $\mathrm{pH}$ and susceptibility can be checked on the basis of the constituents of the original parent rock. All of the three components are interlinked like if any plants residues are added to soil then it will affect the water and nutrient holding capacity of soil which will in turn effect the chemical environment of microorganisms [2].
Effluent is defined by the United States Environmental Protection Agency as "wastewater - treated or untreated - that flows out of a treatment plant, sewer, or industrial outfall. Generally refers to wastes discharged into surface waters". Effluents in the artificial sense are in general considered to be water pollution, such as the outflow from a sewage treatment facility or the wastewater discharge from industrial facilities [3].

Most of the land of district Haripur is used for agricultural purposes. Being Hattar Industrial Estate in Haripur and also due to high 
population of Haripur, there is a lot of pollution. Waste produced by such a high population and the industrial estate is damped into open fields. Dingi is the village which is adjacent to HIE, the larger industries of HIE discharge their effluent into the main stream passing through Dingi. Due to this the soil fertility is affecting. So, it must be studied to lower the effects of industrial effluents by suggesting some better ways. For this problem the null hypothesis given that industrial effluents have no effect on composition of soil while alternative hypothesis given is that the industrial effluents coming from different industries are effecting the composition of soil. Contamination of soil with pig iron slag caused drastic reduction in microbial population [4]. 'Soil fertility' is the important quality of soil which sustains plants and helps them to grow properly [5]. Agricultural land is very fastly decreasing due to increased urbanization and land use for industries. Proper and managed use of available agriculture land is the easy way to overcome the deficiency of land [6].

Due to different anthropogenic activities like industrialization, agricultural activities and sewage disposal, many toxic and radionuclide metals are increasing in the environment [7]. The release of leather industry effluents into the agricultural fields causes indicative changes in nutrient cycling and organic matter processing [8]. Soil being an important system of terrestrial ecosystem has direct effect of pollutants on minerals, organic matter and microbial community [9]. Pollution is increasing due to increased urbanization and industrialization and population. As common practice to damp industrial effluents and wastes is to dispose off them in open fields or water and it is contaminating the soil and ground water as well [10]. Industrialization comes with its effects on life if left with untreated discharge leading to water, soil and sediment pollution [11].

Water is polluted not only by industries but also by households. Industrial pollution has been and continues to be, a major factor causing the degradation of the environment around us, affecting the water we use, the air we breathe and the soil we live on. But of these, pollution of water is arguably the most serious threat to current human welfare [12].

By conducting this research, it can be found /explored that either the industrial effluents have negative or positive effects on soil fertility. To enlist the different effluents being disposed off into the main stream. To study the effect of polluted water on the soil fertility and to study the status of concentration of heavy metals in the soil.

\section{METHODOLOGY}

\subsection{Field Survey}

Field survey was conducted for selection of samples, sites and for selection of various locations to identify the source and extent of pollutions. Samples of water were collected in August 2012 from different sites of study area. In total eight samples were taken from representative sites. Six soil samples were collected three from each of the two fields. One field was near from the main stream that marked polluted and other agriculture field marked as non-polluted lied at distance of 300 $m$ from the stream. All the data gathered were subjected to the statistical analysis.

\subsection{Water Sampling}


A reconnaissance survey was undertaken in May 2012 to assess the bio-physical characteristics of the area and to demark it permanent features for site location of sampling points.

Samples of water were collected from different sites of study area. In total eight samples were taken from representative sites. First sample Al was taken from the main stream passing through village and receiving industrial effluents from neighboring industrial estate Hattar. A2 taken from the same stream at the distance of $100 \mathrm{~m}$ away from $\mathrm{Al}$.

Similarly, B marked samples taken from the home well dug in the nearby houses. $B 1$ is the sample taken from well at the distance of 150 $\mathrm{m}$ from one side of main stream and $\mathrm{B} 2$ is the sample taken from $100 \mathrm{~m}$ away from $\mathrm{B} 1 . \mathrm{C} 2$ is taken at the distance of $150 \mathrm{~m}$ from other side of main stream and C2 is taken at the distance of $100 \mathrm{~m}$ from $\mathrm{C} 3$.

$\mathrm{Cl}$ is taken from tube well at distance of $300 \mathrm{~m}$ from main stream. All samples were collected in clean dry plastic bottles of 1 litre capacity. The bottles and their caps were thoroughly washed with detergent and tap water to ensure the removal of all organic and inorganic chemicals if present. Caps of bottles were tightly closed. Each bottle was marked and labelled in which sample number, date, time and site of collection were included.

Table 1: Loci of water samples in Dingi village

Sr.No Sample.No Location description

\begin{tabular}{|c|c|c|}
\hline 1 & $\mathrm{Al}$ & $\begin{array}{l}\text { Natural stream } \\
\text { receiving effluent of } \\
\text { different industries. }\end{array}$ \\
\hline 2 & $\mathrm{~A} 2$ & $\begin{array}{l}\text { Natural stream } \\
\text { receiving effluents of } \\
\text { industries from } 100 \mathrm{~m} \\
\text { distance. }\end{array}$ \\
\hline 3 & $\mathrm{~B} 1$ & $\begin{array}{l}\text { Sample from home well } \\
150 \text { m distance from one } \\
\text { side of Natural stream. }\end{array}$ \\
\hline 4 & B2 & $\begin{array}{l}\text { Sample from home well } \\
100 \text { m distance from B1. }\end{array}$ \\
\hline 5 & B3 & $\begin{array}{l}\text { Sample from home well } \\
100 \text { m distance from B2. }\end{array}$ \\
\hline 6 & $\mathrm{Cl}$ & $\begin{array}{l}\text { Sample from tube well } \\
300 \text { m distance from main } \\
\text { stream. }\end{array}$ \\
\hline 7 & C2 & $\begin{array}{l}\text { Sample from home well } \\
150 \text { m distance from other } \\
\text { side of main stream. }\end{array}$ \\
\hline 8 & C3 & $\begin{array}{l}\text { Sample from home well } \\
100 \text { m distance from C2. }\end{array}$ \\
\hline
\end{tabular}

\subsection{Laboratory Work}

The analytical work was done in the laboratory by using the standard methods for the examination of wastewater for various parameters. The physical parameters are Temperature, $\mathrm{pH}$, Conductivity, dissolved Solid, Total Suspended Solids, and Turbidity. Chemical analyses were comparing with previous studies to monitor the trend. Atomic absorption spectrometer was used to monitor the concentration of heavy metals in water and soil. Various methods were employed and a comparative record regarding their efficiencies was maintained.

The procedure for determining the $\mathrm{pH}$ of water samples was use of a $\mathrm{pH}$ meter. The temperature was determined by the help of 
mercury thermometer. Electrical conductivity (EC) values of samples were measured with EC metered EC meter was washed with distilled water. The color of each sample was matched with the standards and to measure turbidity meter was calibrated according by. The soil samples were air dried, crushed and sieved via $2 \mathrm{~mm}$ sieve, all preservation standards were followed. Procedure for determining the $\mathrm{pH}$ of soil samples was through use of a $\mathrm{pH}$ meter. The temperature was determined on the spot by the help of mercury thermometer. Electrical conductivity (EC) values of the soil samples were measured with EC meter. Heavy metals were detected by use of atomic spectrometer.

All the data gathered were subjected to the statistical analysis. The mean values of the readings are marked to show the significance of the treatments.

\subsection{Statistical Analysis}

All the data gathered were subjected to the statistical analysis. The mean values of the readings are marked to show the significance of the treatments. These values have been depicted in tabular forms. To check the significance of the results got by the laboratory tests standard deviation method has been applied. These results are shown in tables no. 3 and 4.

\section{RESULTS AND DISCUSSION}

Sampling and analysis of industrial effluents was carried out to identify the pollutants being discharged by industries and evaluate their impacts on soil.

\subsection{Effluents Being Discharged Into the Main Stream}

Haripur is highly industrialized area of Hazara. Various effluents discharged by HIE industries are shown in table 2.

Table 2: Pollutants released in Effluents of different Industries in HIE, Haripur.

\begin{tabular}{|c|c|c|c|}
\hline $\begin{array}{l}\text { S.N } \\
\text { o. }\end{array}$ & Industries & $\begin{array}{l}\text { Effluent } \\
\text { Composition }\end{array}$ & $\begin{array}{l}\text { Formulae of } \\
\text { Composition }\end{array}$ \\
\hline 1 & Chemical & $\begin{array}{l}\text { Phenol } \\
\text { minerals } \\
\text { acids }\end{array}$ & $\begin{array}{l}\text { 2,4,6- } \\
\text { trinitrophenol (T } \\
\text { NP) }\end{array}$ \\
\hline 2 & Fertilizers & Phosphates & $\begin{array}{l}\mathrm{H}_{3} \mathrm{PO}_{4}, \mathrm{~N}_{2} \mathrm{H}_{4} \mathrm{O}_{3} \\
\text { etc. }\end{array}$ \\
\hline 3 & $\begin{array}{l}\text { Food } \\
\text { processing }\end{array}$ & Starch & $\left(\mathrm{C}_{6} \mathrm{H}_{12} \mathrm{O}_{6}\right)_{\mathrm{n}}$ \\
\hline 4 & Soft drinks & Citric acid & $\mathrm{C}_{6} \mathrm{H}_{8} \mathrm{O}_{7}$ \\
\hline 5 & $\begin{array}{l}\text { Petrochemica } \\
\text { । }\end{array}$ & $\begin{array}{l}\text { Hydrocarbo } \\
\text { ns }\end{array}$ & $\mathrm{C}_{3} \mathrm{H}_{8}, \mathrm{C}_{3} \mathrm{H}_{6}$ \\
\hline 6 & Diaries & Sugar & $\mathrm{C}_{2} \mathrm{H}_{6} \mathrm{O}_{2}$ \\
\hline 7 & Galvanizing & Zinc & $\mathrm{Zn}$ \\
\hline 8 & Paint & Lead, paper & $\begin{array}{l}\mathrm{Pb}, \text { mixture of } \\
\text { cellulose }\end{array}$ \\
\hline 9 & $\begin{array}{l}\text { Wood } \\
\text { processing }\end{array}$ & $\begin{array}{l}\text { Zinc, Sugar, } \\
\text { sulphides }\end{array}$ & $\mathrm{Zn}, \mathrm{C}_{2} \mathrm{H}_{6} \mathrm{O}_{2}, \mathrm{H}_{2} \mathrm{~S}$ \\
\hline 10 & Textiles & $\begin{array}{l}\text { Mineral } \\
\text { acid, fats, } \\
\text { oil, }\end{array}$ & $\mathrm{HCl},\left(\mathrm{C}_{3} \mathrm{H}_{5}(\mathrm{OH})_{3}\right)$ \\
\hline 11 & Laundries & $\begin{array}{l}\text { Alkalinity } \\
\text { fats, oils, } \\
\text { greases free } \\
\text { chlorine }\end{array}$ & -- \\
\hline 12 & Electronics & $\begin{array}{l}\text { Zinc, Iron, } \\
\text { Mercury, } \\
\text { Lead }\end{array}$ & $\mathrm{Zn}, \mathrm{Fe}, \mathrm{Hg}, \mathrm{Pb}$ \\
\hline 13 & Glass & Silicon & $\mathrm{Si}$ \\
\hline 14 & Steel & $\begin{array}{l}\text { Iron, } \\
\text { Copper }\end{array}$ & $\mathrm{Fe}, \mathrm{Cu}$ \\
\hline 15 & Plastic & $\begin{array}{l}\text { PVC, } \\
\text { Hydrocarbo } \\
\text { ns }\end{array}$ & $\mathrm{C}_{2} \mathrm{H}_{3} \mathrm{Cl}, \mathrm{C}_{3} \mathrm{H}_{6}$ \\
\hline
\end{tabular}




\begin{tabular}{llll}
\hline 16 & Match & Sulphur, & S, cellulose etc. \\
& Wood & \\
& & residue \\
$17 \quad$ Drugs and & A lot of & -- \\
& pharmaceuti & different \\
cal & chemicals \\
\hline
\end{tabular}

It showed that some of the industries like Galvanizing, Wood processing, and Electronics have same composition of the effluents i.e. $\mathrm{Zn}, \mathrm{Fe}, \mathrm{Hg}$, Pb. Oil seeds crops are used to make ghee and vegetable cooking oils in ghee industries. Different oil seeds like cotton, soybeans, sunflower and palm oils are either crushed or chemically extracted. The pollutants which are released in this process are suspended solids greasy material, Nickel (Ni), resultant High $\mathrm{pH}$, Hydrogen Sulphide (HS), Copper ( $\mathrm{Cu}$ ) and Chromium (Cr).

The textile industries carryout spinning, weaving, bleaching and dying. During textile processing different chemicals used are enzymes, detergents, dyes, acids, and many other salts. The effluents from these industries contain suspended salts, chlorides ( $\mathrm{NaCl}$ ), unused organic / non-organic dyes, heavy metals i.e. $\mathrm{Pb}, \mathrm{Zn}, \mathrm{Ar}, \mathrm{Cd}$ etc.

These industries, although developed with a proper planning are discharging their effluents in the nearby natural drains. The farmers in the vicinity are using these effluents for growing vegetables and cereal crops due to shortage of water.

\subsection{Analysis of Polluted water from Main Stream}

Industrial effluents are the main source of surface and ground water pollution. To evaluate the pollution contents, eight samples from different sites of Dingi as described in methodology were analyzed for various physical and chemical parameters such as temperature, $\mathrm{pH}$, electrical conductivity (EC), turbidity and heavy metals.

\subsection{1 $\mathrm{pH}$}

In the present study, samples A1 and A2 are taken from main stream and their $\mathrm{pH}$ values are 6.4 and 6.3 respectively. While samples B1, B2, B3, C1, C2 and C3 are collected from different home wells and tube wells near the main stream and their values are $7.8,7.8,7.4,6.2,6.6$ and 6.9 respectively. $\mathrm{pH}$ values of all samples fell between 6.2 to 7.8 and within the permissible limit prescribed by National Environmental Quality Standards (NEQS, 1997) and World Health Organization (WHO,1996) for drinking water. Higher $\mathrm{pH}$ values (7.8) recorded near mainstream and tube well was due to higher effluent load and high fertilizer contents used.

\subsubsection{Temperature}

Temperature of the water samples ranged from 4 to 6.5 oC as given in (Table 2). The lowest temperature $\left(4^{\circ} \mathrm{C}\right)$ was recorded in samples B1, B2, B3 and C3 and the highest temperature was that of sample $\mathrm{Cl}$ that is from tube well near to main stream. All the values were within the permissible limits of USEPA and WHO for drinking water standard (Appendix B). The quality of underground water depends on the type of surface because every surface has its own temperature which impacts the water temperature. As the samples were collected in summer season and in summer the temperature of groundwater is always low. 


\subsubsection{Turbidity}

Turbidity expresses the optical property that causes light scattered and absorbed by water. Turbidity in water caused by suspended material such as silt, clay soluble colour organic compounds, and micro organisms and other finely divided organic inorganic matter. Turbidity is bad for water and unfit for human consumption. The process of coagulation and sedimentation can remove particles producing turbidity. The range of turbidity values found in the samples is from 6.5 NTU (Nephlometric Turbidity Unit) to 5 NTU. The high value of turbidity is recorded in the sample $A 1$ and the lower value is recorded in samples B1, B2, B3 and C3. The high value of turbidity is due to the industrial effluents and the other wastes disposed into the main stream Excess amount of turbidity damage the soil fertility.

\subsubsection{Electric Conductivity}

Higher value of conductivity shows that the total dissolve solids are more in number. Its impact on soil is very toxic. No EC values were recorded in analysis in the samples of water collected from research area. It might be due to some chemicals that are coming from the industries and lower the EC.

\subsection{Analysis of Soil Samples from Study Area}

Samples of soil collected from the study site were analyzed in the laboratory and the physical parameters were studied. The results obtained after analysis are given below in the table no. 4 and also discussed.

\subsubsection{Soil $\mathrm{pH}$}

Every soil has its own buffering capacity. Change in $\mathrm{pH}$ value affects the plant nutrients and the level of other elements that may be toxic to higher plants and microorganisms. The higher $\mathrm{pH}$ generally reduces the availability of materials of materials making soils nutrient deficient but protecting them from metal toxicity. The value of polluted soil $\mathrm{pH}$ is 10.11 and non-polluted is 8 . It might be due to heavy metals from the industries and the fertilizers used in the agricultural lands.

\subsubsection{Soil electric conductivity}

The results depicted that the value of EC for polluted soil is $3.0 \mathrm{dsm}-1$ and for nonpolluted soil is $2.9 \mathrm{dsm}-1$. while soil conductivity values 0.6-0.9 are considered fit for cropping. Higher conductivity value of soil is not suitable for cropping [13]. Both the locality from where the soil samples were taken might be regarded as culturally waste.

\subsection{Soil Heavy Metals}

\subsubsection{Zinc (Zn)}

The highest concentration of $\mathrm{Zn}$ in polluted soil is $3.23 \mathrm{ppm}$ and in non-polluted is 2.5 ppm. $\mathrm{Zn}$ is a component of auxin, a hormone regulating plant growth, so insufficient quantity in the plant can lead to stunted growth. Hence the above amounts of zinc were problematic for soil and plants. The high concentration is due the heavy concentration of $\mathrm{Zn}$ coming from the batteries and other electronics industries in their effluents.

\subsubsection{Cadmium $(\mathrm{Cd})$}

The $\mathrm{Cd}$ cannot be detected in both samples of soil. Recent investigation proved that cadmium accumulation with high immobilization was greater in root than shoots to assess exotoxicity in cadmium amended soil [14]. 


\subsubsection{Iron (Fe)}

The value of iron in polluted soil is $1.5 \mathrm{ppm}$ and for non-polluted soil is $2.3 \mathrm{ppm}$. These values of iron found in soil are under permissible limit which is 50.0ppm NEQS set by EPA. The high value of iron recorded is due to the industrial effluent from the steel industries and some other units producing $\mathrm{Fe}$, because there are many units operating in HIE are producing high content of iron in their effluents.

\subsubsection{Arsenic (As)}

Arsenic is a metal like substance found in small amounts in nature. Drinking water containing high level of arsenic may cause health problem. The highest value of As found in polluted soil is 0.8 and for non-polluted soil is 0.5. The concentration of As found in polluted soil is exceeding the permissible layer and it is causing problems.

\subsubsection{Copper ( $\mathrm{Cu})$}

The amount of $\mathrm{Cu}$ available to plants varies widely by soils. Available Cu can vary from 1 to 200 ppm (parts per million) in both mineral and organic soils as a function of soil $\mathrm{pH}$ and soil texture [15]. In the samples analyzed the concentration of $\mathrm{Cu}$ detected in the polluted soil is 0.2 while in non-polluted soil is 0.5 . It might be due the organic nature of soil.

Stunted growth and death of the terminal leaf buds can be associated with $\mathrm{Cu}$ deficiency, since formation and chemical composition of cell walls can be affected. Other symptoms sometimes observed are white leaf tips and narrowed, twisted leaves. From the survey, results have shown that most of the people of Dingi Village are badly affecting due to activities of different industries that are situated in HIE. They usually do not consider the health and environment while taking their daily production decisions. Human health and environment in and around the HIE are at low priority because of ignorance, lack of check and balance system and lack of government's concern. Health problems such as skin allergy, respiratory infections, general allergy, gastritis and ulcer were scanning among the villagers who visited hospital. It was medically accepted that the polluted water had significant influence on these diseases. It was assessed that one-fourth of the villagers has any one of the listed of diseases. Most of the identified patients accepted that they were using either the stream water or well water or both for washing purpose, cleaning the cattle etc. After realizing the ill effects of the water they started avoiding the use of it.

\section{CONCLUSION}

From the above results it is concluded that the soil quality of Dingi village was degraded due to the industrial pollution from HIE and also from unsustainable agricultural activities. The concentration of heavy metals detected in the soil samples showed that there was a high concentration of heavy metals in soil. It was concluded that the harmful effluents were uncontrolled discharge from industries. The legal provisions of PEPA for monitoring and treatment of discharge are not being followed by the management of industries in HIE.

\section{References}

[1] L. K. Abbott, MV. Murphy. Soil biological fertility: A key to sustainable land use in agriculture. Kluwer Academic Publishers, Dordrecht, the Netherlands, (2003) 264. 
[2] http://www.soilhealth.com/soils-arealive/what-is-in-soil/p-01.htm. Accessed on May 112012

[3] http://en.wikipedia.org/wiki/Effluent). Access on May 28, 2012.

[4] M. Balaji, E. Anjaneyulu, M. Ramgopal and G. Narasimha. Effect of Pig Iron Slag Particles on Soil Physico-Chemical, Biological and Enzyme Activities. Iranica Journal of Energy \& Environment 2 (2011) 161-165.

[5] P. Jeeban, Altitudinal Variation of Soil Fertility: A Case Study from Lang tang National Park, Central Department of Environmental Science Tribunal University Katmandu, Nepal, (2010).

[6] S.P. McGrath, F.J. Zhao, and E. Lombi. Plant and rhizosphere process involved in phytoremediation of metal contaminated soils. Plant Soil, 232 (1995) 207-214.

[7] R. H. A. Mohideena, , V. A. Thirumalai, K. R Narayananb and M. I . Z. Hussain, Bioremediation of Heavy metal contaminated soil by the Exigobacterium and Accumulation of $\mathrm{Cd}, \mathrm{Ni}, \mathrm{Zn}$ and $\mathrm{Cu}$ from Soil environment. International Journal of Biological Technology: 1 (2010) 94-101.

[8] G. Narasimha and M. P. Reddi. Effect of leather industry effluents on soil microbial and protease activity. Journal of Environmental Biology, 33 (2012) 39-42.

[9] M. Nagaraju, G. Narasimha. and $V$. Rangaswami, Influence of sugar industry effluents on soil enzyme activities. Ecol. Environ. Cons., 15 (2009) 89-94.
[10] V. Kumar. and O.P. Sagwal, Recent Studies on Soil and Water Pollution in Some Parts of India: A Review. 21 (2000) 186-192.

[11] A.Y. Dada, Evaluation of Kano State Environmental Management Programme1995 on industrial pollution: Case study of Challawa and Sharada Industrial areas, Postgraduate Diploma Dissertation, Department of Geography, Bayero University, Kano (1997).

[12] K. Govindarajalu, Industrial Effluent and Health Status- A Case Study of Noyyal River Basin, Coimbatore, India (2003).

[13] A, Riaz, Effect of Effluents from Hattar Industrial Area on Soil and crop productivity. MPhill Thesis. Department of Biological Sciences, University of Quaid-i-Azam, Islamabad, (2004) 43-58.

[14] A. Younjoo, Environmental Pollution, 127 (2004) 21-26.

[15] G. Rehm and M, Schmitt, Copper for Crop Production. The University of Minnesota, (2009). 